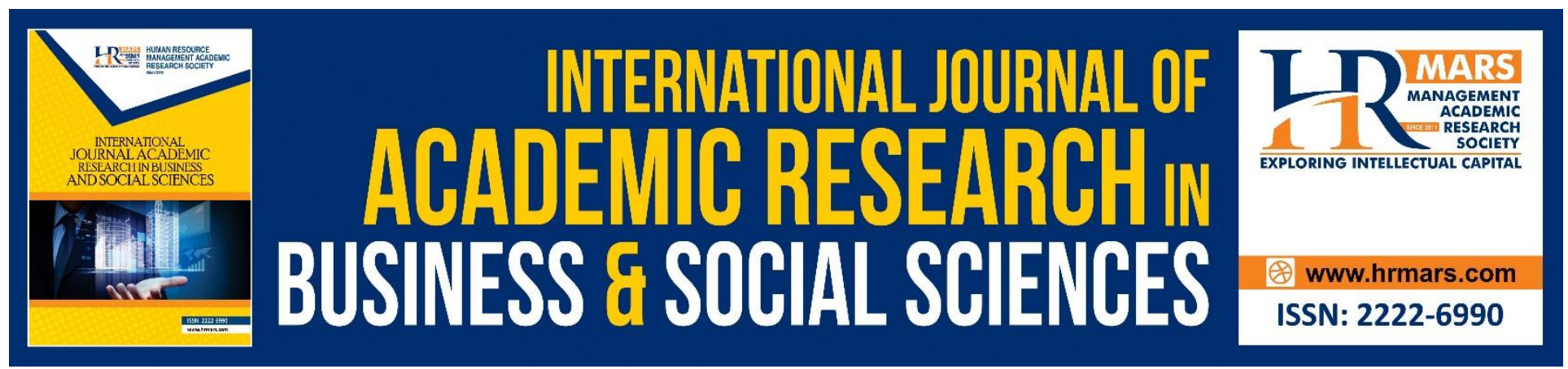

\title{
Factors Affecting Women's Participation in Career: A Systematic Review
}

Rose Chen Siew Kee, Wan Norhayati Wan Othman, Zaida Nor Zainudin \& Yusni Mohamad Yusop

To Link this Article: http://dx.doi.org/10.6007/IJARBSS/v10-i9/7829

DOI:10.6007/IJARBSS/v10-i9/7829

Received: 13 June 2020, Revised: 18 July 2020, Accepted: 20 August 2020

Published Online: 30 September 2020

In-Text Citation: (Kee, Othman, Zainudin, \& Yusop, 2020)

To Cite this Article: Kee, R. C. S., Othman, W. N. W., Zainudin, Z. N., \& Yusop, Y. M. (2020). Factors Affecting Women's Participation in Career: A Systematic Review. International Journal of Academic Research in Business and Social Sciences. 10(9), 509-521.

Copyright: @ 2020 The Author(s)

Published by Human Resource Management Academic Research Society (www.hrmars.com)

This article is published under the Creative Commons Attribution (CC BY 4.0) license. Anyone may reproduce, distribute, translate and create derivative works of this article (for both commercial and non-commercial purposes), subject to full attribution to the original publication and authors. The full terms of this license may be seen

at: http://creativecommons.org/licences/by/4.0/legalcode

Vol. 10, No. 9, 2020, Pg. 509 - 521

http://hrmars.com/index.php/pages/detail/IJARBSS

JOURNAL HOMEPAGE

Full Terms \& Conditions of access and use can be found at http://hrmars.com/index.php/pages/detail/publication-ethics 


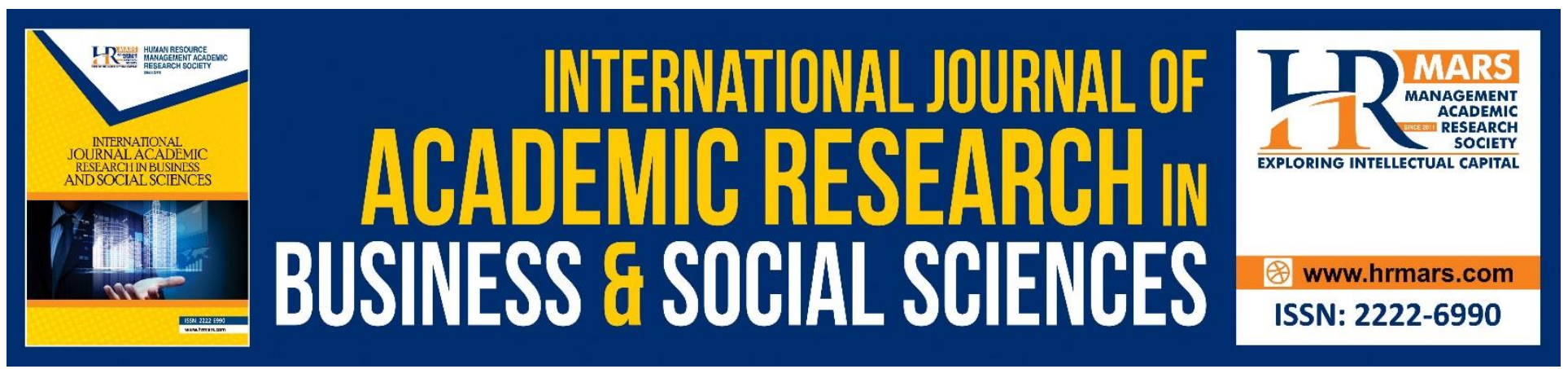

\title{
Factors Affecting Women's Participation in Career: A Systematic Review
}

\author{
${ }^{1}$ Rose Chen Siew Kee, ${ }^{2}$ Wan Norhayati Wan Othman, ${ }^{3}$ Zaida Nor \\ Zainudin \& ${ }^{4}$ Yusni Mohamad Yusop \\ Department of Counselor Education and Counseling Psychology, Faculty of Educational Studies, \\ Universiti Putra Malaysia, Malaysia \\ Email: wannorhayati@upm.edu.my
}

\begin{abstract}
The objective of this study is to understand factors affecting women's participation in career and ways to encourage women's participation in career. Issue of women's participation in career has been hotly discussed around the world. Results from different journal sources conducted in different countries were assimilated to attain better understanding of the factors affecting women's participation in career and ways to encourage women's participant in career. The core of this work builds on highlighting the main findings related to the factors affecting women's participation in career and ways to encourage women's participant in career in Malaysia, United States, Africa and India. The role of counsellor in the counselling session to help the women in their career participation and development has been discussed. The limitation of this review is the selected studies were only limited to Malaysia, United States, Africa, Canada and India.
\end{abstract}

Keywords: Career, Women.

\section{Introduction}

Career is an occupation undertaken for a significant period of a person's life and with opportunities for progress. People work because they need the money (Brown \& Lent, 2013). This may be true for most adults, but work as a means of survival does not tell the whole story, at least not for everyone. As we know, people work for many reasons. Take for example, to earn money, contribute to their families and communities, establish a public identity, reach self-growth and structure their lives. Worldwide, throughout history, one of the most noticeable analysts of virtually all aspects of one's work and career development is the gender. Even though greater gender equity for some men and women had been brought in this recent decades, much effort remains to be done in most countries around the world. In budget 2020 of Malaysia, the government focus on encouraging and enabling the women to return to work (Ishak, 2019). 
The involvement of women in Malaysia in the work sector was recorded among the lowest in the Southeast Asian region behind Cambodia, Myanmar, Thailand and Singapore. About 2,563,800 women in the country are unemployed because they have to take their responsibilities as housewives and take on the responsibilities as a mother (Ishak, 2019). This paper shows the understanding of factors affecting women participation in career. Barrier is all that hinders progression. Women always face the barrier in their job progression. In this world, men and women are treated differently. In my opinion, it does not mean that men and women should be become the same, but that their responsibilities, rights and chances will not depend on whether they are born female or male. Gender equity means treat women and men fairly, according to their own needs. Today, working woman is not a new phenomenon in this world. Women's career development is an issue that is still in the world's attention. It Malaysia, the phenomenon of working women has begun to be accepted by the general public. The working women also had to face various challenges and challenges in the work they did. This challenge includes both physical and mental aspects requiring a high degree of patience. Women are also forced to compete with the men to seize jobs offered by the market. But today women workers have been given the confidence to take a high position in an organization. However there are various challenges that women have to take to get them.

Career development practices and relevance has changed over the past decades However, in order to respond to women's career development needs and remain competitive, the country and organizations must pay attention to what helps them succeed. This systematic review is to study the factors which affect the women's participation in career. Thus, the society play an important role to help women involve in career actively. In short, this systematic review of literatures aims to answer the following objectives:

i. To identify the factors affecting women's participation in career

ii. To identify the ways to increase women's participation in career

\section{Methodology}

This systematic review was started by searching keywords related to factors affecting the women's participation in career through database. Two data bases were used in the search which are Scopus and SAGE database. The following method has been implemented in order to obtain relevance literatures to address the objectives of this review 
INTERNATIONAL JOURNAL OF ACADEMIC RESEARCH IN BUSINESS AND SOCIAL SCIENCES Vol. 10, No. 9, 2020, E-ISSN: 2222-6990 @ 2020 HRMARS
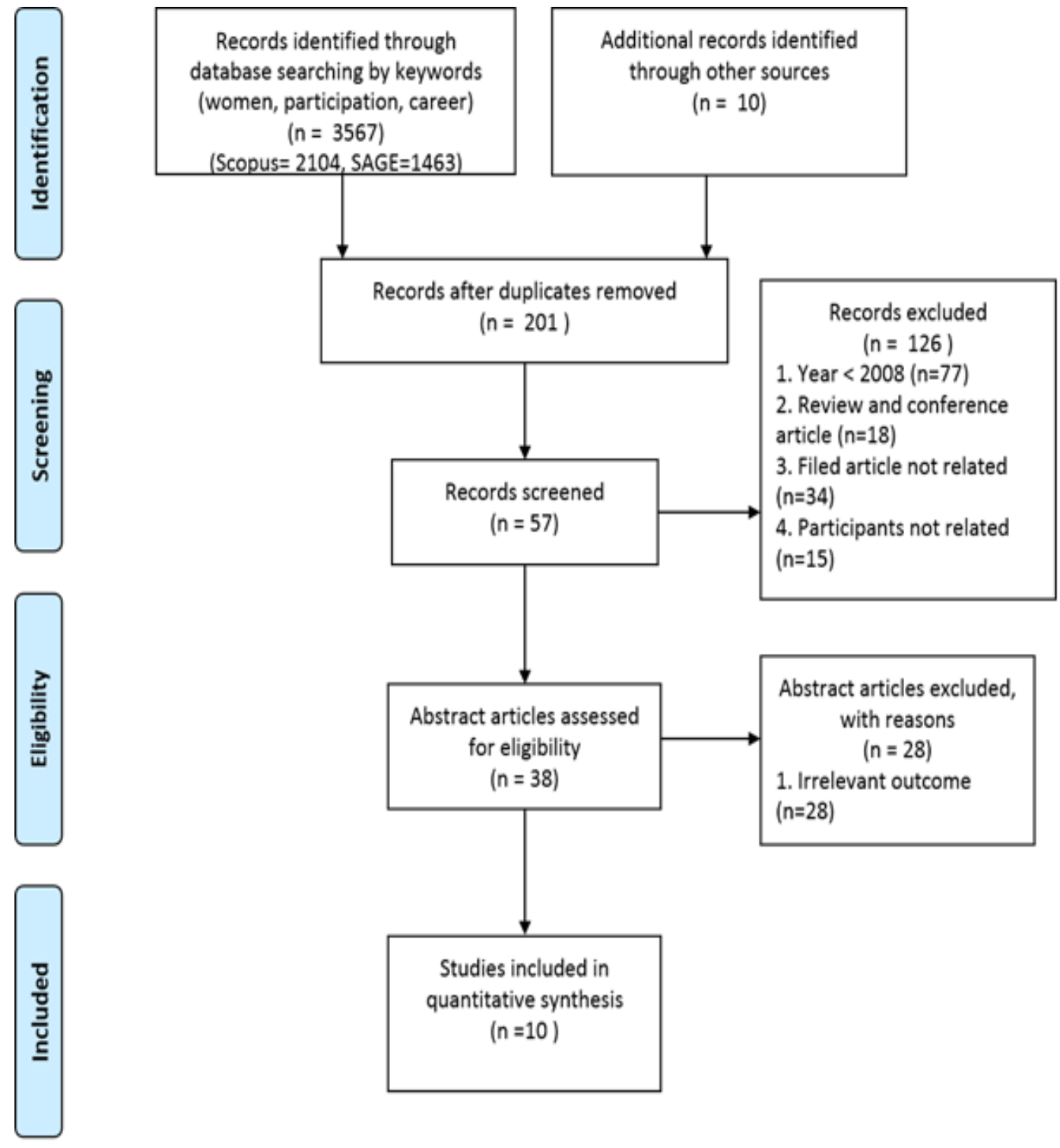

Figure 1: The flow of the systematic review started with initial search using a few key terms.

\section{The Search Strategy}

The reviewer attempted to look for more recent literatures that were published in the past five years (2015 to 2019). However, the limited number of articles broadened the review to articles to the past ten years, which is from year 2008 to 2019. The database (Scopus and SAGE) was used to search the relevance literatures. These database has been accessed under ezaccess website of University Putra Malaysia, UPM.

Three key words which are women, career and participation used to obtain the extended list of literatures. All search related in the Scopus and SAGE are shown in Figure 1. There were 3567 articles found by searching the keywords which are women, career and participation. Records after duplicates removed was 201. For the next step, several inclusion criteria and exclusion criteria are 
INTERNATIONAL JOURNAL OF ACADEMIC RESEARCH IN BUSINESS AND SOCIAL SCIENCES Vol. 10, No. 9, 2020, E-ISSN: 2222-6990 @ 2020 HRMARS

being applied to the search result in order to increase the effectiveness of the searching process, as shown in Figure 1. In order to narrow down the search results, the search area was excluded the articles before year 2008 (77), review and conference articles (18). The field article (34) and participants which were not related (15) also has been excluded. Total 126 articles has been excluded and the outcome was 57 articles. The retrieved papers were screened based on their titles and abstracts. 28 of articles were excluded due to the irrelevant outcome. The search was stopped when 10 most relevant journal articles was found. The articles were studied and reviewed thoroughly.

\section{Findings}

The information of the selected articles pertaining to factors affecting women's participation in career and ways to encourage women's participant in career is shown in Table 1 . The author, year of publication, title of journal articles, setting of the study, participants, and main findings of each literature are clearly outlined. Clearer and better view of the information related to the factors affecting women's participant in career and ways to increase women's participation in career shown in Table 1. The literatures included in this review were studies done in.

Table 1. Summary of selected literatures

\begin{tabular}{|c|c|c|c|c|}
\hline $\begin{array}{c}\text { Author (Year) / } \\
\text { Journal }\end{array}$ & Title of Article & Country & Participants & Main Findings \\
\hline $\begin{array}{c}\text { R. Sujatha (2008) } \\
\text { / } \\
\text { Asia-Pacific } \\
\text { Business Review }\end{array}$ & $\begin{array}{l}\text { Barriers in } \\
\text { career growth } \\
\text { of women } \\
\text { managers: } \\
\text { An Indian } \\
\text { Scenario }\end{array}$ & India & $\begin{array}{l}440 \text { men and } \\
\text { women } \\
\text { managers }\end{array}$ & $\begin{array}{l}\text { Family pressures, } \\
\text { structural barriers and } \\
\text { managerial } \\
\text { stereotypes are the } \\
\text { major factors that thwart } \\
\text { women manager's career } \\
\text { opportunities }\end{array}$ \\
\hline $\begin{array}{c}\text { Noor Rahamah Hj. } \\
\text { Abu Bakar (2012) } \\
\text { Malaysia Journal } \\
\text { of Society and } \\
\text { Space }\end{array}$ & $\begin{array}{c}\text { Working women } \\
\text { and family } \\
\text { management }\end{array}$ & Malaysia & $\begin{array}{l}60 \text { women } \\
\text { respondents }\end{array}$ & $\begin{array}{l}\text { Women are faced with } \\
\text { problems in doing the } \\
\text { housework and also at } \\
\text { the work place }\end{array}$ \\
\hline $\begin{array}{l}\text { Rahmah Ismaila, } \\
\text { Zulkifly Osmanb, } \\
\text { Syazwani A. } \\
\text { Malekc } \\
\text { (2013) }\end{array}$ & $\begin{array}{l}\text { Wage } \\
\text { differences } \\
\text { according to } \\
\text { gender and } \\
\text { employer }\end{array}$ & Malaysia & $\begin{array}{l}347 \text { professional } \\
\text { and executive } \\
\text { workers in the } \\
\text { ICT sector in } \\
\text { Selangor and }\end{array}$ & $\begin{array}{l}\text { Gender wage } \\
\text { differentials is highly } \\
\text { influenced by employers' } \\
\text { bad perception or } \\
\text { discrimination against }\end{array}$ \\
\hline
\end{tabular}


INTERNATIONAL JOURNAL OF ACADEMIC RESEARCH IN BUSINESS AND SOCIAL SCIENCES Vol. 10, No. 9, 2020, E-ISSN: 2222-6990 @ 2020 HRMARS

\begin{tabular}{|c|c|c|c|c|}
\hline $\begin{array}{c}\text { / } \\
\text { Jurnal } \\
\text { Teknologi }\end{array}$ & $\begin{array}{c}\text { discrimination in } \\
\text { the information } \\
\text { and } \\
\text { communication } \\
\text { technology } \\
\text { sector }\end{array}$ & & $\begin{array}{l}\text { Federal } \\
\text { Territory of } \\
\text { Kuala Lumpur. }\end{array}$ & $\begin{array}{l}\text { women, whereby the } \\
\text { contribution of this } \\
\text { portion is close to } 80 \\
\text { percent. }\end{array}$ \\
\hline $\begin{array}{c}\text { Suhaida Mohd } \\
\text { Amin, Mohd Faizal } \\
\text { bin P. Rameli } \\
\text { (2014) } \\
\text { / } \\
\text { Prosiding PERKEM } \\
\text { ke-9 }\end{array}$ & $\begin{array}{c}\text { The } \\
\text { phenomenon of } \\
\text { shortage of } \\
\text { educated and } \\
\text { skilled women in } \\
\text { Malaysia }\end{array}$ & Malaysia & 1083 women & $\begin{array}{l}\text { Working women will quit } \\
\text { their jobs, and those } \\
\text { who do not work will } \\
\text { choose not to work } \\
\text { when faced with issues } \\
\text { of lack of work and } \\
\text { family balance, as well as } \\
\text { childcare issues. }\end{array}$ \\
\hline $\begin{array}{c}\text { Brooke E. D., } \\
\text { Alexander Y. D., } \\
\text { Robert D. R., \& } \\
\text { Niwako Yamawaki } \\
\text { (2017) } \\
/ \\
\text { Malaysian Journal } \\
\text { of Society and } \\
\text { Space }\end{array}$ & $\begin{array}{l}\text { No girls allowed: } \\
\text { Women } \\
\text { in male- } \\
\text { dominated } \\
\text { majors } \\
\text { experience } \\
\text { increased } \\
\text { gender } \\
\text { harassment and } \\
\text { bias } \\
\end{array}$ & $\begin{array}{l}\text { United } \\
\text { States }\end{array}$ & $\begin{array}{l}146 \text { male and } \\
\text { female students } \\
\text { in male- } \\
\text { dominated (MD) } \\
\text { and } \\
\text { gender- } \\
\text { equivalent (GE) } \\
\text { majors }\end{array}$ & $\begin{array}{l}\text { Implicit bias among men } \\
\text { from MD majors. } \\
\text { Women from MD majors } \\
\text { experienced significantly } \\
\text { more gender harassment } \\
\text { than women from GE } \\
\text { majors. }\end{array}$ \\
\hline $\begin{array}{c}\text { Tracy Soidi, } \\
\text { Agnis Sombuling } \\
\text { (2016) } \\
\text { / } \\
\text { Southeast Asia } \\
\text { Psychology } \\
\text { Journal }\end{array}$ & $\begin{array}{l}\text { The effect of } \\
\text { work and family } \\
\text { conflicts on } \\
\text { parental } \\
\text { satisfaction } \\
\text { among working } \\
\text { mothers }\end{array}$ & Malaysia & $\begin{array}{l}105 \text { mothers } \\
\text { worked in } \\
\text { administration } \\
\text { at one of the } \\
\text { public } \\
\text { universities in } \\
\text { Kota Kinabalu, } \\
\text { Sabah }\end{array}$ & $\begin{array}{l}\text { High family-work } \\
\text { conflicts bring low } \\
\text { parenting satisfaction } \\
\text { among working mothers. }\end{array}$ \\
\hline $\begin{array}{c}\text { Anella T. M., } \\
\text { Ephantus. K. \& } \\
\text { Pemela. A. O. } \\
\text { (2016) } \\
\text { / } \\
\text { International } \\
\text { Journal Of } \\
\text { Scientific \& } \\
\text { Technology } \\
\text { Research } \\
\end{array}$ & $\begin{array}{c}\text { Factors } \\
\text { influencing } \\
\text { women's career } \\
\text { progression to } \\
\text { leadership } \\
\text { positions in } \\
\text { Harare City } \\
\text { Council, } \\
\text { Zombabwe }\end{array}$ & Africa & $\begin{array}{l}116 \\
\text { respondents }\end{array}$ & $\begin{array}{l}\text { The civil society } \\
\text { organizations should } \\
\text { implement gender } \\
\text { deconstruction programs } \\
\text { in societies such that } \\
\text { women will not be } \\
\text { confined to the } \\
\text { traditionally expected } \\
\text { roles }\end{array}$ \\
\hline
\end{tabular}


INTERNATIONAL JOURNAL OF ACADEMIC RESEARCH IN BUSINESS AND SOCIAL SCIENCES Vol. 10, No. 9, 2020, E-ISSN: 2222-6990 @ 2020 HRMARS

\begin{tabular}{|c|c|c|c|c|}
\hline $\begin{array}{c}\text { Donna Bobbitt- } \\
\text { Zeher } \\
(2011) \\
\text { / } \\
\text { Gender \& Society }\end{array}$ & $\begin{array}{l}\text { Gender } \\
\text { discrimination } \\
\text { at work: } \\
\text { Connecting } \\
\text { gender } \\
\text { stereotypes, } \\
\text { institutional } \\
\text { policies, and } \\
\text { gender } \\
\text { composition of } \\
\text { workplace }\end{array}$ & $\begin{array}{l}\text { United } \\
\text { States }\end{array}$ & $\begin{array}{l}219 \\
\text { discrimination } \\
\text { Narratives } \\
\text { constructed } \\
\text { from sex } \\
\text { discrimination } \\
\text { cases brought } \\
\text { before the Ohio } \\
\text { Civil } \\
\text { Rights } \\
\text { Commission. }\end{array}$ & $\begin{array}{l}\text { Gender stereotyping } \\
\text { combines in predictable } \\
\text { ways with sex } \\
\text { composition of } \\
\text { workplaces and } \\
\text { organizational policies, } \\
\text { often through } \\
\text { interactional dynamics of } \\
\text { discretionary policy } \\
\text { usage, to result in } \\
\text { discrimination. }\end{array}$ \\
\hline $\begin{array}{l}\text { Bardekjian, A. C., } \\
\text { Nesbitt, L., } \\
\text { Konijnendijk, C. C., } \\
\text { \& Lotter, B. T. } \\
\text { (2019) } \\
\text { / } \\
\text { Urban Forestry \& } \\
\text { Urban Greening }\end{array}$ & $\begin{array}{l}\text { Women in } \\
\text { urban forestry } \\
\text { and } \\
\text { arboriculture: } \\
\text { Experiences, } \\
\text { barriers and } \\
\text { strategies for } \\
\text { leadership. }\end{array}$ & $\begin{array}{l}\text { Canada/ } \\
\text { United } \\
\text { States }\end{array}$ & $\begin{array}{l}515 \text { women } \\
\text { working in } \\
\text { urban forestry } \\
\text { or arboriculture }\end{array}$ & $\begin{array}{l}74 \% \text { had experienced } \\
\text { sexist behaviour or } \\
\text { harassment, and } 84 \% \\
\text { had experienced } \\
\text { workplace barriers that } \\
\text { were gender-based. The } \\
\text { strategies suggested to } \\
\text { promote women's } \\
\text { leadership were } \\
\text { sponsorship/mentoring, } \\
\text { confidence, } \\
\text { communication, work- } \\
\text { life balance, and career } \\
\text { planning, with } \\
\text { suggestions varying by } \\
\text { barrier experienced. }\end{array}$ \\
\hline $\begin{array}{c}\text { Shannon B. } \\
\text { Juengst, Alexa } \\
\text { Royston, Isabel } \\
\text { Huang, Brittany } \\
\text { Wright } \\
\text { (2019) } \\
\text { / } \\
\text { JAMA Network } \\
\text { Open }\end{array}$ & $\begin{array}{l}\text { Family leave } \\
\text { and return-to- } \\
\text { work } \\
\text { experiences of } \\
\text { physician } \\
\text { mothers }\end{array}$ & $\begin{array}{l}\text { United } \\
\text { States }\end{array}$ & $\begin{array}{l}844 \\
\text { respondents }\end{array}$ & $\begin{array}{l}\text { Support at the } \\
\text { institutional level, such } \\
\text { as paid leave, adequate } \\
\text { breast pumping time } \\
\text { without penalty, on-site } \\
\text { childcare, and schedule } \\
\text { flexibility, would likely } \\
\text { provide the greatest } \\
\text { direct assistance to help } \\
\text { physician mothers thrive } \\
\text { in their careers. }\end{array}$ \\
\hline
\end{tabular}

\section{Discussions}

The contribution of women in the economy, especially the jobs has had a profound impact on the country's economic growth. Existing employment opportunities lead the women hold various positions in career. According to llagan-Bian (2004), women faced many challenges in moving up such 
INTERNATIONAL JOURNAL OF ACADEMIC RESEARCH IN BUSINESS AND SOCIAL SCIENCES Vol. 10, No. 9, 2020, E-ISSN: 2222-6990 @ 2020 HRMARS

as non-supportive bosses or colleagues, sexual discrimination and male chauvinism. It is important to women to make success on the job, but equally significant for them is their wish to start a family (Racene, 2014). However, the most important thing is not to lose balance between the personal life and the job. Thus, the factors affecting women's participation in career and ways to increase their participation in career are studied.

\section{Factors Affecting Women's Participation in Career Work and Family Conflicts}

Sujatha (2008) studied that family pressures, structural barriers and managerial stereotypes are the major factors that thwart women manager's career opportunities. The executives also feel the maternity variable mostly affect the progress of a career woman. Maternity causes working women to take career break and women has to face the problem arising out of work and family balance. Abu Bakar (2012) states that working women always face dilemmas in dividing their duties in the workplace and managing the household. They have to do a lot of household at home and have lack of time to do all the work at one time including taking care of children. In the workplace, they faced some problems such as unfair promotion procedures. Women who play the role of mother and employee face the role conflicts arising from the conflict between the obligations of the family and work. Women will face variety of problems at work and at home. This can become the barrier for women to advance in their careers and hold high level positions in their company. According to Abu Bakar (2012), there is a kindergarten teacher and four clerks who stopped working because want to focus on nurturing their children.

Nowadays, changing roles in the family are increasingly appearing especially among women, where this group not only plays a role as a mother but also as an employee. In general, work and family conflicts occur as a result of decreased involvement of women in career field (Maphul \& Abdullah, 2011). According to Yaves et al. (2008), work and family conflicts have been found to have a more negatives impacts to female workers than male workers. Most of the women are still responsible for household and parenting is still the main responsibility for women.

Study of Amin \& Rameli (2014) shows that respondents state that child care issues (18.8 percent), family-management problems and unpleasant working environment problems (11.4 percent each) were the reasons that lead them to stop and resign from their work. The problem of balancing career and family also creates a conflict, which causes unmarried respondents to state that family management and child care issues are factors that will cause them to stop working. This findings support previous studies that more married women stopped working because of child care and household management problems (Abdullah, Ismail, Noor, \& Ahmad, 2012).

According to Soidi \& Sombuling (2016), a woman play a role as a mother is expected to responsible for nurturing and educating the child, while as an employee is expected to play a role in doing her job at work. This situation will cause conflicts to the women workers. The role of a mothers in this work increased according to the findings of Stewards (2000), which found that working mothers had low parental satisfaction compared to unemployed mothers. It can also explain the influence of family-work conflict on the parental satisfaction of women. Overall, the role of working mother affects parenting satisfaction, which a working mother who is in conflict to carry out her 
INTERNATIONAL JOURNAL OF ACADEMIC RESEARCH IN BUSINESS AND SOCIAL SCIENCES Vol. 10, No. 9, 2020, E-ISSN: 2222-6990 @ 2020 HRMARS

responsibilities as a mother due to high workplace demands will contribute to her low parental satisfaction. While the women always have the low parental satisfaction, they will feel stress and unhappy for their work. At the end, they will choose to quit their work and become a housewife at home.

\section{Low Wages}

According study of Abu Bakar (2012), the women respondents felt dissatisfied with their salary. They are paid less than what they are supposed to. Difference of wages between men and women influences the women participation in one career (Ismail, Osman \& Malek, 2013). This difference is due to discrimination practices of the employer referred to as unexplained factors. In fact, employees are paid according to employer perceptions of their productivity. In this situation, female workers are considered to have lower productivity than male workers, even though they have the same level of education. As a result, women are paid lower wages. According to the National Employment Report (Ministry of Human Resources, 2008), the average wage for women workers was lower, at RM1, 239 compared to wage of male worker which is RM1, 473. Similarly, women's employment was lower compared to male employment, which is $34.3 \%$ in 2000 out of total employment, but increased to 34.5\% and 34.6\% respectively in 2005 and 2010 respectively. This phenomenon causes negative implication for the labour market because discrimination can lead to discontent among women workers. This also will lead the women workers not to contribute optimally in the work place.

\section{Stereotypes}

The impression about gender has been transferred into discriminatory behaviours through gender stereotyping. According to Bobbitt-Zeher (2011), prescriptive and descriptive gender stereotypes is differentiated by cognitive psychologists. Descriptive stereotypes is beliefs about trait that one gender has; prescriptive stereotypes involve beliefs about traits one gender ought to have. Men always underestimate the ability women at work. Men and the community did not to provide the necessary support or privilege to women (Badariah, Noratiqah \& Mapjabil, 2016). Generally women requires support from the husband, parents and family to build confidence for working. Bardekjian, Nesbitt, Konijnendijk, \& Lotter (2019) found that 74\% of 515 women respondents had experienced sexist behaviour or harassment, and $84 \%$ of 515 women respondents had experienced workplace barriers that were gender-based. Discrimination was the most commonly-experienced barrier according to this study.

These stereotypes have affected the participation of women in career. People always think that women are physically and mentally weak so it is not worthy of being a leader. Women are full of limitations, not as men. Men's activities are more liberal, free, more qualified, and productive. All this stereotypes affect women in workplace. Some reasons for the low rate of women's participation in work are regarding the perception of the work of women in relation to the domestic role of women. Second, relating to the device of measurement, determination, or defining the work of women. Besides, the part-time and informal nature of most female occupations. This shows these barriers that result in weak market information, business services, limited access to career, and lack of disincentive reserve and constraints for women to pursue the career world. 
INTERNATIONAL JOURNAL OF ACADEMIC RESEARCH IN BUSINESS AND SOCIAL SCIENCES Vol. 10, No. 9, 2020, E-ISSN: 2222-6990 @ 2020 HRMARS

\section{Ways to Increase Women's Participation in Career}

It is important for organizations to encourage women to join the labour market and provide them with career opportunities in order to help women who have the dual role of addressing the problems of domestic and work environment. Education, training and counselling are needed for women workers (Abu Bakar, 2012). Due to the special needs of some women, it is necessary to plan and give counselling to women related to short-term and long-term employment prospects. It is desirable for women workers to have advanced education and training so as to avoid the difference in skills. Workplaces can support women via programming and workplace structures, and are also personal skills that women can develop through personal and professional development opportunities (Bardekjian, Nesbitt, Konijnendijk \& Lotter, 2019). Women should be encouraged to get training for a particular job that provides opportunities in terms of career development while earning good income. Advanced education is especially important in professional work group. These education, training and counselling will motivate more women continue working. Designing a specific leadership development program tailored for women's career needs may give women a chance to learn from other successful individuals' ways to overcome career challenges (Jouharah, 2018). In addition, internal training programs also should be established in the company for male and female employees share issues related to their perceptions, stereotypes, myths and feelings about the role of women in an organization. The goal here is to try to change the views of male workers on their female colleagues and at the same time encouraging male workers support and do not threaten female workers.

The organizations should provide bias free environment, organizations should realize the role of the employer, HR Manager and the peer employees (Sujatha, 2008). The whole process followed by the stake holders must go through the procedure of gender proofing and gender mainstreaming in order to avoid any form of gender differential effects on the employees. This would surely lead to develop a gender friendly work environment to the employees. Thus, the present day organizations must recognize that the provisions made for women through HR policy is not an incentive, but is the duty to uphold the rights of working women. Anella, Ephantus \& Pemela (2016) recommended that family friendly policies should be put in place in order to minimize the pressure that being physically present at their workplace. Male-dominated majors, university faculty and staff in male-dominated majors should work to help those who are affected by setting an example of acceptance and inclusiveness and creating mentorship programs in order to overcome the gender harassment in work place (Brooke, Alexander, Robert, \& Yamawaki, 2017). In order to reduce implicit bias stereotyping women as associated with family and men as associated with careers among men in male-dominated majors, an open dialog, as well as bias workshops, can be used to decrease these biases in the long term

Facilities and adequate time for pumping breast milk should be provided by the employer (Juengst, Royston, Huang, Wright, 2019; Darwish, Abdo, \& AlShuwaiee, 2018). This can encourage the mother participant in career. Besides, organizations also need to pay attention for child-care facilities in the workplace (Zainuddin, Khalid \& Talib, 2018). Practical childcare facilities have become a major obstacle for women in the family to remain in the job. Women with their family-friendly features have made them leave their work or find a more flexible job in ensuring the safety of their 
INTERNATIONAL JOURNAL OF ACADEMIC RESEARCH IN BUSINESS AND SOCIAL SCIENCES Vol. 10, No. 9, 2020, E-ISSN: 2222-6990 @ 2020 HRMARS

children. According to the result, the top five strategies suggested to promote women's leadership were sponsorship/mentoring, confidence, communication, work-life balance, and career planning,

\section{Conclusion}

The understanding of factors affecting women participation in career has expanded to acknowledge the importance of career counselling. The role and function of the counsellor is very important in helping women in career. This is to say that the counsellor needs to possess the sensitivity, knowledge and skills of working with issues that are of particular concern to career needs and experiences of women nowadays (Pauline \& Charles, 2007). A comprehensive and situational understanding of the career psychology of women can be greatly enhanced if the counsellor can connect the career development theoretical models to a client's career problems, experiences, and needs in her social and personal reality. Counsellors need to familiarize themselves with research and scholarship on the relationship between gender and career development (Brooks \& Forrest, 1994). Besides, counsellors need to be aware of the sociocultural barriers that hinder women in the workplace and be committed to understanding women in a societal context (Chae, 2002).

Super's concept of life roles seems to have particular relevance to career counselling women clients. Career counselling should provide the client with the unique opportunity for exploring the complexity as well as the dynamic interaction between various life roles in her life career journey. The helping process should aim to assist the client to gain a better understanding of the gender socialisation influences in the function of these life roles she assumes. Based on that, the counsellor can facilitate the client to generate ideas and coping methods that can integrate these life roles in ways of facilitating rather than hindering her life career wellbeing (Sumari, Norfaezah \& Norsafatul, 2015). As such, the counsellor helps the client define and prioritise the dimensions of each role and search for more optimal role combinations in order to achieve balance in life.

There are few limitations in this systematic reviews. One of the limitations is that the selected studies were only limited to Malaysia, United States, Africa, Canada and India. This means the review only reflects the factors affecting women's participation and the ways to encourage them in participating in career in these countries. Therefore, this review cannot be generalized for the all the wives and children from polygamous families. These 10 studies were conducted to a small size of respondents from a small region, so it is hard to generalize the results and findings.

This literature review is significant in furthering understanding about the factors affecting women's participation in career and ways to encourage their participation in career. Although women are known to have multi-tasking, only in recent years, many have become aware of the importance of women's employment engagements in the economy. Women's contributions are beginning to be recognized and women are given formal education and women are also given the trust to hold higher positions in the job. Various parties need to play an important role in addressing the challenges and problems participation of women in career in Malaysia. It was found that the role of the parties, especially the government, could affect the women's employment. In order to ensure that the measures taken are more effective, the parties should work together to develop flexible female employment in Malaysia. The welfare of women workers should not be neglected as they are important to sacrifice and contribute to the country's economy and development. Women workers 
INTERNATIONAL JOURNAL OF ACADEMIC RESEARCH IN BUSINESS AND SOCIAL SCIENCES

Vol. 10, No. 9, 2020, E-ISSN: 2222-6990 @ 2020 HRMARS

should be rewarded with the granting of protection which involves the importance of working. Hopefully, women will be stronger and stronger in the face of competition with men in all areas of work and increase the career involvement of women in future. Working women better understand their working nature and having a family.

\section{Acknowledgement}

This research received no specific grant from any funding agency in the public, commercial or notfor-profit sectors.

\section{Corresponding Author}

Wan Norhayati Wan Othman

Department of Counsellor Education \& Counselling Psychology

Faculty of Educational Studies

Universiti Putra Malaysia

Email:wannorhayati@upm.edu.my

\section{References}

Abdullah, N., Ismail, R., Noor, M. Z., \& Ahmad, F. (2012). Kebarangkalian Bekerja Wanita Berkahwin di Malaysia (Probability of Working among Married Woman in Malaysia). Jurnal Ekonomi Malaysia, 46(1), 107-117.

Abu Bakar, N. R. (2012). Wanita bekerja dan pengurusan keluarga. Malaysia Journal of Society and Space, 7, 155-162.

Abu Bakar, N. R. (2014). Gender dan pekerjaan di Malaysia: Perlunya tempat kerja yang 'mesra wanita'. Malaysian Journal of Society and Space, 10(6), 179-186.

Anella, T. M., Ephantus, K., \& Pemela, A. O. (2016). Factors influencing women's career progression to leadership positions in Harare City Council, Zombabwe. International Journal of Scientific \& Technology Research, 5(5), 95-102.

Badariah, A. R., Noratiqah, A. S., \& Mapjabil, J. (2016). Ciri dan pengaruh stereotaip feminin terhadap pengurusan dalam kalangan penjawat awam (The features and implication of feminine stereotypes in public service management). Malaysian Journal of Society and Space. 12(14), 10-18.

Bardekjian, A. C., Nesbitt, L., Konijnendijk, C. C., \& Lotter, B. T. (2019). Women in urban forestry and arboriculture: Experiences, barriers and strategies for leadership. Urban Forestry \& Urban Greening, 46.

Bobbitt-Zeher, D. (2011). Gender Discrimination at Work: Connecting Gender Stereotypes, Institutional Policies, and Gender Composition of Workplace. Gender \& Society, 25(6), 764786.

Brooks, L., \& Forrest, L. (2019). Feminism and career counselling. Career counselling for women, 87-134.

Brooke E. D., Alexander Y. D., Robert D. R., \& Yamawaki, N. (2017). No girls allowed: Women in male-dominated majors experience increased gender harassment and bias. Malaysian Journal of Society and Space, 1-16.

Brown, S. D., \& Lent, R. W. (2013). Career Development and Counselling: Putting Theory and Research to Work. New Jersey: John Wiley \& Sons, Inc. 
INTERNATIONAL JOURNAL OF ACADEMIC RESEARCH IN BUSINESS AND SOCIAL SCIENCES Vol. 10, No. 9, 2020, E-ISSN: 2222-6990 ๑ 2020 HRMARS

Chae, M. (2002). Counseling reentry women: An overview. Journal of Employment Counseling, 39, 146-152.

Darwish, S., Abdo, H., \& AlShuwaiee, W. M. (2018). Opportunities, challenges and risks of transition into renewable energy: the case of the Arab Gulf Cooperation Council. International Energy Journal, 18(4).

Ilagan-Bian, J. (2012). This leader is a woman! Cebu Daily News, http://www.inq7.net

Ismail, R., Osman, Z., \& Malek, S. A. (2013). Perbezaan Upah Mengikut Jantina dan Diskriminasi Majikan dalam Sektor Teknologi Maklumat dan Komunikasi. Jurnal Teknologi, 63:1, 41-50.

Jouharah, M. A. (2018). Women's career development in an Arab Middle Eastern context. Human Resource Development International, 1-15.

Juengst, S. B., Royston, A., Huang, I., \& Wright, B. (2019). Family leave and return-to-work experiences of physician mothers. JAMA Network Open, 2(10).. 1- 15.

Kementerian Sumber Manusia. (2008). Upah Pokok Bulanan Purata Pekerja Mengikut Jantina dan Kategori Pekerjaan, Malaysia. Percetakan Selaseh Sdn Bhd.

Ishak, M. (2019). Belanjawan 2020 mesra wanita. Berita Harian. Retrieved from https://www.bharian.com.my

Maphul, I. N., \& Abdullah. (2011). The prevaleence of work-family conflict among mothers in peninsular Malaysia. International journal of humanities and social science, 154-161.

Mate, S. E., McDonald, M., \& Truc, Do. (2018). The barriers and enablers to career and leadership development: An exploration of women's stories in two work cultures. International Journal of Organizational Analysis

Amin, M. S., \& Rameli, M. F. (2016). Fenomena Kekurangan Tenaga Kerja Wanita Berpendidikan dan Berkemahiran di Malaysia. Prosiding PERKEM, ke-9.. 269-277.

Pauline, A. C., \& Charles, P. C. (2007). Career development and counselling for women: connecting theories to practice. Counselling Psychology Quarterly, 20(2), 191-204.

Racene. (2014). Development of Women's career pattern in relation of employment. Baltic Journal of Career Education and Management, 2(1), 16-23.

Soidi, S., \& Sombuling, A. (2016). Pengaruh Konflik Kerja dan Keluarga terhadap Kepuasan Keibubapaan dalam kalangan Ibu Bekerja. Southeast Asia Psychology Journal, 4, 17-23.

Sujatha. (2008). Barriers in career growth of women managers: An Indian scenario. Asia-Pacific Business Review, IV (3), 108-116.

Sumari, M., Md Kalid, N., \& Razak, N.A. (2015). Teori dan amalan kaunselinng kerjaya. Kuala Lumpur: Penerbit UM.

Yaves, U., Babakus, E., Karatepe, O. M. (2008). Attitudinal and behavioral consequences of workfamily conflict and family-work conflict: does gender matter? International journal of service industry management. 7-31.

Zainuddin, A., Khalid, K., \& Talib, A. (2018). Konsep mengarusperdanakan gender: Kajian wanita dalam pekerjaan di Malaysia. Journal of Administrative Science, 15(1), 1-10. 